\title{
Other Route of Administration
}

National Cancer Institute

\section{Source}

National Cancer Institute. Other Route of Administration. NCI Thesaurus. Code C38290.

Route of drug administration not specified on this list. 